Counsellia: Jurnal Bimbingan dan Konseling, 10 (1), $2020 \mid 14-27$

Copyright (C2020 Universitas PGRI Madiun

ISSN: 2088-3072 (Print) / 2477-5886 (Online)

Available online at: http://e-journal.unipma.ac.id/index.php/JBK

DOI: 10.25273/counsellia.v10i1.4988

\title{
Biblio-Journaling sebagai optimalisasi peran Ayah pada 1000 Hari Pertama Kehidupan (1000 HPK)
}

\author{
Devi Putri Iswandari ${ }^{1}$, Iswari Hariastuti ${ }^{2}$, Tyas Martika Anggriana ${ }^{3}$, Silvia Yula \\ Wardani $^{4}$ \\ ${ }^{1}$ FKIP, Universitas PGRI Madiun, Madiun \\ devipoetry2@gmail.com \\ ${ }^{2}$ Perwakilan BKKBN Jawa Timur, Surabaya \\ iswarihariastuti@yahoo.com \\ ${ }^{3}$ FKIP, Universitas PGRI Madiun, Madiun \\ tyas.ma@gmail.com \\ ${ }^{4}$ FKIP, Universitas PGRI Madiun, Madiun \\ via.ardhanie@gmail.com
}

\begin{abstract}
Abstrak
Stunting adalah sebuah masalah kesehatan yang berkaitan dengan malnutrisi kronis yang terjadi pada anak dan masih menjadi perhatian pemerintah Indonesia dalam upaya penanganannya. Artikel ini bertujuan untuk mengetahui peran biblio-journaling untuk optimalisasi peran ayah pada 1000 Hari Pertama Kehidupan (1000 HPK) sebagai upaya menurunkan prevalensi stunting. Metode penelitian yang digunakan adalah eksperimen menggunakan one group pre-test post-test design. Subjek penelitian diambil secara purposive dengan kriteria seorang ayah yang sedang memiliki anak yang berusia di bawah tiga tahun. Jumlah sampel adalah 20 orang. Metode pengumpulan data menggunakan angket yang disusun berdasarkan indikator peran ayah dalam pengasuhan 100 Hari Pertama Kelahiran. Hipotesis penelitian diuji menggunakan Wilcoxon Sign Rank Test. Hasil dari penelitian yang telah dilaksanakan dapat membuktikan bahwa bibliojournaling dapat meningkatkan pemahaman ayah tentang stunting sehingga peran ayah pada 1000 Hari Pertama Kehidupan (100 HPK) menjadi optimal sebagai upaya menurunkan prevalensi stunting.
\end{abstract}

Keywords: Bibliotherapy, Journaling Therapy, Peran Ayah, 1000 HPK, Stunting

\begin{abstract}
Stunting is a health problem related to chronic malnutrition that occurs in children and is still a concern of the Indonesian government in its handling efforts. This article aims to study the role of biblio-journal to optimize the role of fathers in the First 1000 Days of Life (1000 HPK) as an effort to increase the prevalence of stunting. This study used an experimental research method with one group of pre-test and post-test design. The research subjects were 20 fathers taken purposively with the criteria being having children under three years old. The data collection method uses a questionnaire that is based on indicators of the role of fathers in the care of the First 100 Days of Life (1000 $H P K)$. Research hypotheses were tested using the Wilcoxon sign rank test. The results of the research prove that biblio-journaling can increase father's understanding of stunting so that the father's role in the First 1000 Days of Life (100 HPK) is optimal as an effort to reduce prevalence of stunting.
\end{abstract}


Keywords : Bibliotherapy, Journaling Therapy, Father's Role, 1000 HPK, Stunting

\section{PENDAHULUAN}

Kualitas kesehatan merupakan salah satu aspek penting yang turut menentukan kemajuan bangsa. Stunting adalah salah satu permasalahan yang belum bisa tertangani dan membutuhkan perhatian khusus di Indonesia. Hal ini seperti pidato yang disampaikan oleh Presiden Republik Indonesia Joko Widodo pada Musyawarah Rencana Pembangunan Nasional (Musrenbangnas) RPJMN 2020-2024, bahwa angka stunting (kekerdilan) di Indonesia masih tergolong tinggi sehingga pemerintah menargetkan penurunan angka stunting menjadi 14\% pada tahun 2024 (Kementerian PPN/Bappenas, 2019). Berdasarkan Studi Status Gizi Balita Terintegrasi Susenas 2019 diketahui angka kejadian stunting di Indonesia adalah 27,67\% (Izwardy, 2020; Pritasari, 2020). Jika dibandingkan dengan nilai batas kesehatan masyarakat yang ditetapkan oleh WHO maka angka tersebut masuk ke dalam golongan prevalensi sedang; sedangkan angka yang harus dicapai sebagai nilai batas kesehatan masyarakat yang bebas stunting adalah kurang dari $20 \%$ (WHO, 2010).

Setiawan (2018) mendefinisikan stunting sebagai kondisi gagal tumbuh yang terjadi pada anak balita yang disebabkan oleh kondisi kekurangan gizi kronis yang terjadi sejak masih di dalam kandungan hingga lahir, namun baru dapat terlihat pada usia 2 tahun. Kondisi ini mengakibatkan anak memiliki tinggi badan terlalu pendek jika dibandingkan dengan anak seusianya yang tumbuh normal. Secara jangka panjang, stunting seringkali dapat menyebabkan perkembangan mental yang tertunda, masalah akademik/sekolah dan berkurangnya kapasitas intelektual (WHO, 2010). Hal senada disampaikan oleh Atmarita (2018) yang memberikan definisi stunting sebagai kondisi yang dialami oleh anak yang berusia $0-59$ bulan yang memiliki tinggi badan sesuai usia berada di bawah -2SD (minus 2 Standar Deviasi) dari standar median WHO. Kondisi tersebut dapat berdampak dan terkait dengan gangguan proses perkembangan otak; sehingga secara jangka pendek dapat mempengaruhi kemampuan kognitif anak, sedangkan secara jangka panjang dapat membatasi akses pemerolehan pendidikan yang lebih baik dan berpengaruh pada berkurangnya kesempatan untuk mendapatkan peluang kerja dengan pendapatan yang lebih baik. Pada masa dewasanya, anak stunting cenderung akan menjadi gemuk/obese dan berpeluang menderita penyakit tidak menular atau penyakit degeneratif (Atmarita, 2018). Secara lebih lengkap, Kementrian Desa, Pembangunan Daerah Tertinggal, dan Transmigrasi (2017), menguraikan ciri-ciri anak stunting meliputi: a) Pertumbuhan melambat, b) Anak menjadi lebih pendiam dan tidak banyak melakukan eye contact pada umur 8-10 tahun; c) Wajah terlihat lebih muda jika dibandingkan dengan usianya; d) Mengalami keterlambatan tanda pubertas; e) Mengalami performa buruk ketika dilakukan tes perhatian dan memori belajar; dan f) Pertumbuhan gigi terlambat. Berdasarkan pendapat beberapa tokoh tersebut dapat disimpulkan pengertian stunting adalah sebuah kondisi gagal tumbuh yang dialami oleh anak balita akibat kekurangan asupan gizi sejak dalam kandungan; sehingga secara jangka pendek dapat mengakibatkan dampak fisiologis, seperti tinggi badan lebih pendek jika dibandingkan dengan anak seusia yang tumbuh normal, tanda pubertas terlambat, ketika dewasa berpotensi menderita penyakit degeneratif, dan sejenisnya; dan secara jangka panjang menyebabkan dampak non fisiologis, seperti mengalami masalah akademik, terbatasnya peluang kerja, dan sejenisnya.

WHO (2014) menguraikan faktor-faktor yang berkontribusi terhadap terjadinya stunting diantaranya adalah:

a. Kesehatan dan gizi ibu yang buruk. Faktor ini meliputi status gizi dan kesehatan ibu sebelum, selama dan setelah kehamilan; perawakan pendek; jarak kelahiran pendek dan kehamilan remaja yang mengganggu ketersediaan nutrisi bagi janin (karena tuntutan persaingan pertumbuhan ibu yang sedang berlangsung). Atmarita (2018) juga menjelaskan bahwa proses terjadinya stunting dimulai dari pra-konsepsi, yaitu 
ketika seorang remaja menjadi ibu yang kurang gizi dan anemia; dan ketika masa kehamilan kurang mendapatkan asupan gizi yang seharusnya mencukupi kebutuhan. Berdasarkan hasil Survei Nasional Konsumsi Makanan Individu Tahun 2014 diketahui bahwa sebagian besar ibu hamil, baik yang tinggal di desa maupun di kota, bermasalah dengan asupan energi dan protein. Kondisi tersebut akan menjadi lebih parah ketika ibu hidup di lingkungan dengan sanitasi kurang memadai.

b. Praktik pemberian makan bayi dan anak yang tidak memadai. Praktik pemberian makan bayi dan anak kecil yang berkontribusi terhadap stunting mencakup pemberian ASI suboptimal (khususnya, pemberian ASI non-eksklusif) dan pemberian makanan pendamping ASI yang terbatas dalam jumlah, kualitas, dan variasi. Berdasarkan survey Nasional yang dilakukan sekitar tahun 2012-2017 diketahui bahwa bayi yang mendapatkan ASI eksklusif tidak sampai 50\% (Atmarita, 2018).

c. Infeksi. Infeksi subklinis, akibat paparan pada lingkungan yang terkontaminasi dan kebersihan yang buruk menjadi penyebab stunting karena malabsorpsi nutrisi dan berkurangnya kemampuan usus untuk berfungsi sebagai penghalang terhadap organisme penyebab penyakit. Penyakit menular yang parah, yang mungkin memiliki konsekuensi jangka panjang terhadap pertumbuhan tergantung pada tingkat keparahan, durasi dan kekambuhan, terutama jika tidak ada makanan yang cukup untuk mendukung pemulihan.

d. Kondisi kemiskinan rumah tangga, pengabaian pengasuh, praktik pemberian makan yang tidak responsif, stimulasi anak yang tidak memadai, dan kerawanan pangan juga dapat menghambat pertumbuhan dan perkembangan.

Berdasarkan paparan faktor tersebut dapat dipahami bahwa pemberian nutrisi yang tidak memadai adalah salah satu penyebab terjadinya stunting. Kondisi gagal tumbuh seringkali dimulai sejak janin masih berada dalam kandungan dan berlanjut setelah lahir. Hal ini mencerminkan praktik menyusui yang tidak optimal, pemberian makanan komplementer serta pengendalian infeksi yang tidak memadai. Oleh karena itu, penting untuk memperhatikan pengasuhan pada masa 1000 Hari Pertama Kehidupan, terhitung sejak masa kehamilan hingga anak berusia 2 tahun (WHO, 2014).

Kondisi ini diduga berkontribusi pada siklus malnutrisi antargenerasi. Stunting sangat menguras produktivitas dan pertumbuhan ekonomi. Oleh karena itu, berbagai upaya perlu dilakukan untuk mengurangi prevalensi stunting. WHO (2014) menyarankan beberapa upaya yang dapat dilakukan meliputi:

1. meningkatkan identifikasi, pengukuran dan pemahaman stunting dan meningkatkan cakupan kegiatan yang diarahkan untuk mencegah stunting;

2. menetapkan kebijakan dan/atau memperkuat intervensi yang diarahkan pada peningkatan status gizi dan kesehatan ibu, termasuk pada anak perempuan remaja;

3. melaksanakan intervensi untuk peningkatan praktik pemberian ASI eksklusif dan pemberian makanan tambahan; dan

4. penguatan intervensi berbasis masyarakat, diantaranya peningkatan air, sanitasi dan kebersihan (WASH), untuk melindungi anak dari penyakit diare dan malaria, cacing usus dan penyebab infeksi subklinis lingkungan.

Stunting tidak hanya terkait dengan permasalahan gizi yang dialami oleh anak, namun juga berhubungan dengan hal penting lainnya. Oleh karena itu, penanganannya ditingkat keluarga perlu melibatkan peran ayah dan ibu secara proporsional. Pandangan tradisional yang banyak dianut oleh masyarakat memposisikan peran pengasuhan lebih dibebankan kepada ibu. Namun, seiring dengan perkembangan zaman, pandangan tersebut mulai berubah. Kini muncul pandangan mengenai peran orang tua yang bersifat androgini, yaitu antara ayah dan ibu memiliki peran dan fungsi yang relatif sama dalam 
pengasuhan (Hidayati et al., 2011). Berdasarkan hasil penelitian yang dilakukan oleh Hidayati et al. (2011) diketahui bahwa seiring meningkatnya jumlah ibu bekerja menyebabkan ayah mendapatkan tuntutan peran dan partisipasi yang lebih besar dalam kehidupan keluarga. Peran ayah tidak hanya terbatas pada mencari nafkah namun juga terlibat membimbing dan mengasuh anak di rumah. Dengan demikian dapat disimpulkan bahwa pengasuhan anak merupakan tugas bersama antara ayah dan ibu. Hal ini diperkuat dengan amanat yang tertuang dalam Undang-undang No. 36 tahun 2009 tentang Kesehatan yang menyebutkan bahwa upaya pemeliharaan kesehatan bayi dan anak menjadi tanggung jawab dan kewajiban bersama bagi orang tua, keluarga, masyarakat, dan Pemerintah, dan pemerintah daerah (Undang-Undang Nomor 36 Tahun 2009 Tentang Kesehatan, 2009).

Ayah adalah figur penting dan utama dalam menjalankan peran menanggulangi stunting. Peran ayah menjadi lebih kuat jika mendapatkan dukungan dari ibu dan anggota keluarga lainnya. Upaya pencegahan dan penanggulangan stunting dengan melibatkan peran ayah meliputi (Redaksi Sahabat Keluarga, 2018):

a. Menjadi figur dalam menciptakan keharmonisan keluarga, termasuk memberikan ketenangan, keamanan dan kenyamanan

b. Peduli dan berperan aktif dalam mengasuh, mendidik dan memberikan perlindungan kepada anak dan ibu

c. Memastikan kecukupan asupan gizi pada saat ibu sedang hamil, meliputi asupan protein, karbohidrat, lemak, vitamin, dan mineral. Oleh karenanya, ayah harus selalu memperhatikan kecukupan dan ketersediaan bahan makanan di rumah serta membantu ibu mengelola sumber daya keluarga untuk kecukupan zat gizi

d. Mengajak dan mendampingi ibu yang sedang hamil melakukan pemeriksaan kehamilan minimal 4 kali untuk memantau kondisi kehamilan dan antisipasi kemungkinan munculnya gangguan supaya bisa dideteksi dan ditangani sejak dini

e. Mendampingi ibu yang sedang hamil dengan penuh kasih sayang sehingga terbebas dari tekanan

f. Memastikan bahwa ibu hamil dan anak menjadi prioritas dalam pemberian makanan yang sehat, bergizi dan bervarisi dalam keluarga

g. Memastikan ketersediaan air bersih dan sehat serta bebas dari bahan dan mikroorganisme yang membahayakan

h. Memastikan kondisi sanitasi rumah memadai

i. Memberikan pengasuhan positif kepada anak

j. Memberikan teladan penerapan PHBS (Perilaku Hidup Bersih dan Sehat)

k. Memastikan setiap anggota keluarga memperoleh akses layanan kesehatan yang memadai.

1. Memastikan balita rutin ditimbang di Posyandu untuk memantau status gizinya

Upaya optimalisasi peran ayah dalam pengasuhan sebagai upaya menurunkan prevalensi stunting yang dilakukan dalam pada penelitian ini menggunakan teknik bibliojournaling pada 1000 Hari Pertama Kehidupan (1000 HPK). Teknik ini merupakan perpaduan antara teknik bibliotherapy dan journaling therapy yang diterapkan pada 1000 Hari Pertama Kehidupan (1000 HPK). Masa 1000 HPK dimulai saat janin masih berada di dalam kandungan (270 hari) dan berlanjut hingga anak berusia 2 tahun (730 hari) (Direktorat Pembinaan Pendidikan Keluarga, 2019). Hal yang paling diperlukan pada masa tersebut adalah pemenuhan gizi dan pemberian stimulasi guna memfasilitasi tumbuh kembang anak secara optimal.

Istilah bibliotherapy terdiri dari dua kata, yaitu biblio, yang berasal dari kata Yunani biblus (buku), dan therapy, mengacu pada bantuan psikologis. Fokus utamanya adalah pada konten yang disajikan dalam buku dan relevansinya dengan kesulitan atau masalah 
seseorang (Shechtman, 2009). Bibliotherapy yang dikenal dengan banyak nama, diantaranya bibliocounseling, biblioeducation, bibliopsychology- merupakan teknik treatment yang populer pada profesi pemberi bantuan, misalnya konselor, psikolog dan psikiater (Herlina, 2013). Bibliotherapy merupakan proses membantu orang dengan menggunakan buku, terlepas dari usia mereka atau status social, memahami dan mengelola tantangan psikologis, sosial dan emosional. Bibliotherapy membantu meningkatkan kesejahteraan individu, kepercayaan diri, dan kualitas hidup secara keseluruhan. Ini bisa menjadi cara yang praktis dan tidak terlalu mencolok dalam mempelajari cara-cara baru untuk mengatasi tantangan hidup (Oluwaseye, 2017).

Eliasa (2011) mengatakan bahwa bibliotherapy merupakan suatu prosedur tindakan terapeutik yang mencakup tugas membaca bahan bacaan yang terseleksi, terencana, dan terarah dan diyakini dapat mempengaruhi sikap, perasaan dan perilaku individu sesuai dengan yang diharapkan serta dapat merangsang pembaca untuk berfikir. Bibliotherapy mudah dilaksanakan, murah dan bisa dilakukan kapan saja serta melibatkan kemandirian dan partisipasi pembaca secara penuh untuk menginternalisasikannya.

Johnson (2012) menjelaskan journaling therapy sebagai tindakan menuliskan pikiran dan perasaan untuk memilah-milah masalah dan sampai pada pemahaman yang lebih dalam tentang diri sendiri dan masalah inti kehidupan seseorang. Selanjutnya menurut Erford (2016) melalui kegiatan menulis jurnal, klien dimungkinkan bisa mengungkapkan dan mengeksternalisasikan pikirannya, perasaannya, dan kebutuhannya; dimana hal-hal yang ditulis tersebut bisa berupa ekspresi yang biasanya disimpan hanya untuk ranah internal/pribadi. Journaling menjadi sebagai sebuah teknik terapi ketika di bawa ke dalam sesi konseling dan dibahas bersama konselor secara terbuka, serta menjadi penggerak proses konseling. Lent \& Young (Erford, 2016) menyarankan kegiatan menulis jurnal dilakukan setiap hari, disesuaikan dengan kebutuhan dan pedomannya disepakati bersama antara konselor dan klien. Langkah umum yang dapat diikuti dalam menulis jurnal adalah: 1) Menjelaskan maksud dan isi penulisan jurnal; 2) Melibatkan diri dalam kegiatan journaling; 3) Memeriksa kemajuan klien serta melibatkannya dalam diskusi yang bermakna berdasarkan isi dan proses penulisan jurnal; 4) Menyemangati klien dan memodifikasi kegiatan bilamana dianggap perlu.

Johnson (2012) pernah melakukan penelitian dengan cara mengintegrasikan bibliotherapy dan journaling therapy bersama dengan pengobatan tradisional untuk membantu memfasilitasi pemulihan gangguan penggunaan narkoba dengan klien AfrikaAmerika. Dia sering memberikan klien tugas pekerjaan rumah pada tahap pemulihan awal dengan menugaskan klien membaca buku yang disarankan, diikuti dengan penjurnalan pada bacaan tersebut. Bahan bacaan yang dipilih berkaitan dengan permasalahan yang ditangani, sebagai tahap pemulihan dasar dan membangun harapan. Selanjutnya melalui teknik journaling klien diminta untuk membuat jurnal wawasan yang mereka dapatkan dengan membaca bahan bacaan tersebut, diikuti dengan diskusi dalam sesi konseling. Tahap ini ditujukan untuk memotivasi klien dalam menghadapi tantangan hidup.

Pada penelitian ini, bibliotherapy akan dipadukan dengan journaling therapy yang bertujuan untuk meningkatkan pemahaman ayah tentang stunting sehingga bisa mengoptimalkan peran ayah pada 1000 HPK. Dalam penerapannya ayah akan diberi bahan bacaan sebagai bagian dari proses konseling kelompok yang isinya mengenai Optimalisasi Peran Ayah Pada 1000 Hari Pertama Kehidupan (HPK). Bahan bacaan tersebut berisi informasi tentang stunting. Bahan bacaan disiapkan secara khusus oleh peneliti agar sesuai dengan tujuan penelitian. Langkah ini bertujuan untuk memberikan pengetahuan dan keterampilan kepada anggota keluarga -khususnya ayah- tentang cara 
mengasuh, memperhatikan asupan gizi yang baik serta pemeliharaan kesehatan ibu hamil dan balita. Selanjutnya ayah akan diberi lembar journaling atau catatan harian yang digunakan untuk mencatat, merefleksi dan menuangkan pemahaman dan permasalahan yang dialami ayah selama mendampingi ibu hamil dan anak balita. Hasil pemahaman melalui bahan bacaan dan refleksi dari lembar journaling selanjutnya digunakan sebagai bahan penyelenggaraan konseling kelompok.

Secara sederhana, Folastri dan Rangka (2016) mendefinisikan konseling kelompok sebagai bentuk layanan dalam format kelompok dengan memanfaatkan dinamika kelompok yang berguna untuk membantu menyelesaikan permasalahan pribadi yang dialami oleh anggota kelompok. Sedangkan menurut Sanyata (2010), konseling kelompok adalah salah satu jenis strategi layanan konseling yang menekankan pada interaksi sosial anggota dan ditujukan untuk mengubah perilaku anggota kelompok berdasarkan interaksi kelompok itu serta dapat diterapkan pada anak-anak, remaja, dewasa dan lanjut usia yang disesuaikan dengan karakteristik perkembangan mereka. Dengan demikian dapat disimpulkan bahwa konseling kelompok merupakan sebuah bentuk layanan dalam bimbingan dan konseling yang dapat diterapkan pada periode perkembangan mulai dari anak-anak hingga lansia dan ditujukan untuk membahas dan menyelesaikan masalah pribadi yang dialami oleh anggota dengan memanfaatkan dinamika kelompok.

Berdasarkan uraian tersebut maka penerapan teknik biblio-journaling yang dipadukan dengan layanan konseling kelompok diharapkan dapat diterapkan untuk optimalisasi peran ayah pada 1000 Hari Pertama Kehidupan sebagai upaya menurunkan prevalensi stunting. Dampak jangka panjang yang diharapkan adalah anak dapat tumbuh secara sehat, cerdas, produktif dan terbebas dari stunting.

\section{METODE PENELITIAN}

\section{Rancangan Penelitian}

Penelitian menggunakan metode eksperimen. Menurut Arikunto (2013), metode penelitian eksperimen adalah metode penelitian yang dimaksudkan untuk mengetahui ada tidaknya akibat dari sesuatu yang dikenakan pada subjek selidik. Rancangan penelitian eksperimen yang dipilih adalah quasi experimental dengan one group pretest posttest design. Arikunto (2010) mengemukakan bahwa desain penelitian ini dilaksanakan pada satu kelompok saja tanpa kelompok pembanding.

\section{Sumber Data}

Populasi dalam penelitian ini adalah Ayah yang memiliki balita dengan jumlah 54 . Teknik pengambilan sampel menggunakan teknik purposive sampling. Teknik purposive sampling adalah teknik penetapan responden untuk dijadikan sampel berdasarkan kriteriakriteria tertentu (Siregar, 2011). Sampel yang diambil disesuaikan dengan karakteristik penelitian yaitu ayah yang memiliki anak dengan usia 0-2 tahun dengan jumlah 20 orang di Desa Dawuhan Kabupaten Trenggalek.

\section{Teknik Pengumpulan Data}

Teknik pengumpulan data dalam penelitian ini menggunakan angket. Angket adalah teknik pengumpulan informasi yang memungkinkan analis mempelajari sikapsikap, keyakinan, perilaku, dan karakteristik beberapa orang utama di dalam organisasi yang bisa terpengaruh oleh system yang diajukan atau oleh system yang sudah ada (Siregar, 2011). Penelitian ini menggunakan angket tertutup dengan menggunakan skala likert. Skala likert digunakan untuk mengukur sikap, pendapat dan persepsi seseorang tentang suatu objek atau fenomena tertentu (Siregar, 2011). Skala likert memiliki dua pernyataan yaitu pernyataan positif dan negative. Alternatif jawaban yang digunakan 
adalah sangat setuju, setuju, tidak setuju, sangat tidak setuju yang masing-masing memiliki nilai tersendiri pada jawaban yang diberikan. Dengan indikator angket diantaranya Penyedia Fasilitas serta akses air bersih dan sanitasi untuk pencegahan stunting, Sebagai penjamin kesejahteraan dalam keluarga pada 1000 Hari Pertama Kehidupan anak, Pemberi perlindungan dan pengawasan selama masa kehamilan pada 1000 Hari Pertama Kehidupan, Pendamping dan Pendukung Ibu hamil hingga 1000 Hari Pertama Kehidupan, Pendidik dan pemberi teladan pada 1000 Hari Pertama Kehidupan.

\section{Teknik Analisis Data}

Sesuai dengan tujuan penelitian, maka analisis data dalam penelitian ini menggunakan statistic nonparametric dengan rumus uji Wilcoxon sign rank test. Sugiyono (2008) berpendapat bahwa statistik nonparametik dapat digunakan jika jumlah sampel kecil dan distribusinya tidak mengikuti sebaran normal dan tidak menggambarkan distribusi populasi darimana sampelnya diambil; menggunakan runk data atau orginal data; serta menggunakan data nominal. Uji wilcoxon ini digunakan untuk menguji signifikansi hipotesis komparatif dua sampel yang berkolerasi bila datanya berbentuk ordinal.

\section{HASIL DAN PEMBAHASAN}

\section{Hasil Penelitian}

Berdasarkan hasil uji statistik, berikut akan dipaparkan distribusi frekuensi data pretest pada Tabel 1 dan data post-test pada Tabel 2.

Tabel 1. Distribusi Frekuensi Peran Ayah pada 1000 HPK sebelum diberikan Biblio-Journaling

\begin{tabular}{cccc}
\hline Interval & Frekuensi & Persentase & Skala \\
\hline $30-48$ & 0 & $0 \%$ & Sangat Rendah \\
\hline $49-66$ & 3 & $15 \%$ & Rendah \\
\hline $67-84$ & 10 & $50 \%$ & Sedang \\
\hline $85-102$ & 7 & $35 \%$ & Tinggi \\
\hline $103-120$ & 0 & $0 \%$ & Sangat Tinggi \\
\hline Jumlah & 20 & $100 \%$ & \\
\hline
\end{tabular}

Paparan data pada Tabel 1 terlihat bahwa kategori tertinggi pemahaman ayah dalam peran pengasuhan selama 1000 HPK terkait stunting berada pada kategori sedang, yaitu sebesar 50\%; sedangkan yang termasuk kategori tinggi terdapat 35\%. Adapun distribusi frekuensi peran ayah pada 1000 HPK setelah diberikan biblio-journaling therapy dapat dilihat pada Tabel 2.

Tabel 2. Distribusi Frekuensi Peran Ayah pada 1000 HPK setelah diberikan Biblio-Journaling

\begin{tabular}{cccc}
\hline Interval & Frekuensi & Prosentase & Skala \\
\hline $30-48$ & 0 & $0 \%$ & Sangat Rendah \\
\hline $49-66$ & 0 & $0 \%$ & Rendah \\
\hline $67-84$ & 1 & $5 \%$ & Sedang \\
\hline $85-102$ & 16 & $80 \%$ & Tinggi \\
\hline $103-120$ & 3 & $15 \%$ & Sangat Tinggi \\
\hline Jumlah & 20 & $100 \%$ & \\
\hline
\end{tabular}

Paparan data pada Tabel 2 terlihat bahwa kategori tertinggi pemahaman ayah dalam peran pengasuhan selama 1000 HPK terkait stunting berada pada kategori tinggi, yaitu sebesar 80\%; sedangkan yang termasuk kategori sangat tinggi terdapat $15 \%$. 
Selanjutnya akan dipaparkan descriptive statictic masing-masing kelompok data dapat dilihat pada Tabel 3.

Tabel 3. Descriptive Statistic

\begin{tabular}{lrrrrr}
\hline & $N$ & Minimum & Maximum & Mean & Std. Deviation \\
\hline Pretest & 20 & 58 & 94 & 71,15 & 10,654 \\
\hline Posttest & 20 & 84 & 106 & 95,75 & 6,060 \\
\hline Valid N (listwise) & 20 & & & & \\
\hline
\end{tabular}

Paparan data pada Tabel 3 menunjukkan mean skor post-test subjek penelitian yaitu 95.75; lebih besar dari mean skor pretest subjek penelitian yaitu 71.15. Untuk mengetahui kebermaknaan secara statistik perbedaan tersebut, selanjutnya dilakukan uji wilcoxon. Adapun hasil uji wilcoxon dapat dilihat pada Gambar 1 dan Tabel 4.

Tabel 4. Hasil Uji Wilcoxon Signed Rank

\begin{tabular}{|c|c|c|c|c|}
\hline \multicolumn{5}{|c|}{ Ranks } \\
\hline & & $N$ & Mean Rank & Sum of Ranks \\
\hline \multirow[t]{4}{*}{ Posttest - Pretest } & Negative Ranks & $0^{\mathrm{a}}$ &, 00 &, 00 \\
\hline & Positive Ranks & $19^{\mathrm{b}}$ & 10,00 & 190,00 \\
\hline & Ties & $1^{\mathrm{c}}$ & & \\
\hline & Total & 20 & & \\
\hline \multicolumn{5}{|c|}{ a. Posttest $<$ Pretest } \\
\hline \multicolumn{5}{|c|}{ b. Posttest $>$ Pretest } \\
\hline \multicolumn{5}{|c|}{ c. Posttest $=$ Pretest } \\
\hline
\end{tabular}

Memperhatikan uraian data pada Tabel 4 diketahui bahwa terdapat 19 data yang memperlihatkan adanya peningkatan. Rata-rata peningkatan sebesar 10.00. Oleh karena itu dapat dikatakan bahwa ada 19 orang subjek penelitian yang mendapatan skor post-test lebih tinggi daripada skor pre-testnya. Selanjutnya skor ties menunjukkan angka 2, artinya terdapat 1 orang subjek penelitian yang skor pre-testnya sama dengan skor posttestnya. Berdasarkan paparan data tersebut maka diketahui bahwa pemahaman peran ayah dalam pengasuhan pada 1000 HPK tentang stunting mengalami peningkatan. Untuk lebih jelasnya, pada Gambar 1 disajikan grafik visualisasi uji wilcoxon.

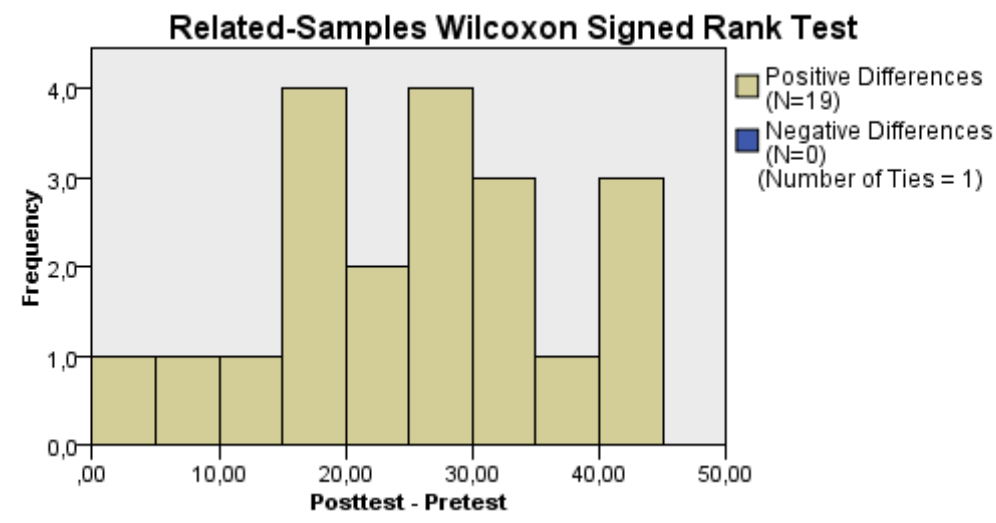

Gambar 1. Grafik Visualisasi Uji Wilcoxon Signed Rank

Analisis data dilanjutkan dengan perhitungan $\mathrm{Z}$ score untuk mengetahui perbedaan skor pre-test dan post-test. Berdasarkan hasil uji statistik, Z score-nya adalah -3,824; taraf 
signifikansi yang digunakan $0.000(\mathrm{p}<0.05)$. Visualisasi hasil perhitungan $\mathrm{Z}$ score diuraikan pada Tabel 5.

Tabel 5. Hasil Perhitungan Z Score

\begin{tabular}{lr}
\multicolumn{2}{c}{ Test $^{2}$ Statistics $^{a}$} \\
\hline$Z$ & Posttest - Pretest \\
\hline Asymp. Sig. (2-tailed) & $-3,824^{\mathrm{b}}$ \\
\hline
\end{tabular}

Berdasarkan hasil perhitungan statistik yang dipaparkan diatas terlihat perbedaan yang signifikan antara hasil pretest dan hasil posttes. Hal ini berarti bahwa ayah memiliki peningkatan pemahaman tentang peran pengasuhan stunting pada 1000 HPK. Dengan demikian dapat disimpulkan bahwa biblio-journaling dapat digunakan untuk meningkatkan peran ayah dalam pengasuhan pada 1000 HPK.

\section{Pembahasan}

Stunting merupakan salah satu permasalahan kesehatan di Indonesia yang belum terselesaikan dan harus ditangani secara serius. Hal ini penting karena anak merupakan salah satu aset bangsa di masa depan dan bisa dibayangkan kondisi sumber daya manusia di masa yang akan datang jika saat ini banyak anak Indonesia yang terkena stunting. Tumbuh kembang anak menjadi generasi yang sehat tidak terlepas dari peran pengasuhan keluarga. Hal ini sejalan dengan pendapat Rakhmawati (2015) bahwa peran pengasuhan anak yang dilakukan oleh keluarga salah satunya bertujuan untuk mengetahui tahap perkembangan anak. Peran pengasuhan dilakukan secara bersamasama oleh ibu dan ayah. Meskipun ibu dan ayah memiliki perbedaan dalam penerapan pola pengasuhan, namun keduanya dapat saling melengkapi kekurangan masing-masing dalam mengasuh anak menjadi lebih fleksibel dan efektif. Masrul (2019) menjelaskan bahwa praktik asuhan psikososial berupa upaya pemberian stimulus dan dukungan emosional kepada anak selama proses tumbuh kembangnya yang dilakukan oleh pengasuh (ibu, ayah, atau orang lain) dibutuhkan untuk mencegah terjadinya stunting.

Tingkat pengetahuan orang tua juga turut mempengaruhi status kesehatan anak. Tingkat pengetahuan gizi yang rendah dapat menjadikan pola asuh kurang sehingga mempengaruhi kejadian stunting pada balita (Ibrahim \& Faramita, 2015; Ni'mah \& Muniroh, 2015; Rahayu \& Khairiyati, 2014). Selain tingat pengetahuan, tipe kepribadian pengasuh juga dapat mempengaruhi status kesehatan anak. Hasil penelitian yang dilakukan oleh Suca, dkk (2019) menunjukkan fakta bahwa tipe kepribadian yang dimiliki oleh ibu dikatakan turut mempengaruhi terjadinya stunting pada anak. Ibu dengan tipe kepribadian A bisa menunjukkan sikap terburu-buru dalam proses feeding. Hal ini dapat mengganggu kenyamanan anak dalam menghabiskan makanannya sehingga efeknya adalah tidak terjadi peningkatan kualitas dan kuantitas makanan anak. Apalagi jika makanan yang diberikan kepada anak kurang mencukupi kebutuhan zat gizi. Oleh karena itu, kebiasaan ini jika berlangsung secara terus menerus dalam jangka waktu yang lama maka dapat menjadi potensi terjadinya stunting.

Selain peran ibu, peran ayah juga dibutuhkan dalam pengasuhan anak. Peran ayah dalam kehidupan anak sangat penting, baik dari segi interaksi secara langsung, pemantauan dan kontrol aktifitas anak serta kebutuhan anak. Ismiyati (2019) mengatakan bahwa upaya pencegahan stunting dapat dilakukan pada 1000 HPK, salah satunya dilakukan pada pemantauan kehamilan. Dukungan keluarga salah satunya dari suami/ayah sangat dibutuhkan untuk melakukan hal ini. Selain itu, peran ayah juga diharapkan untuk membantu menjaga status gizi, meskipun peran tersebut tidak dapat dilakukan secara maksimal karena waktu yang dimiliki ayah lebih banyak dipergunakan 
di tempat kerja. Selain itu, Herwanti (2017) mengatakan bahwa ada hubungan yang bermakna antara peran ayah dalam mencari nafkah dengan status gizi balita, karena jika penghasilan ayah meningat maka daya beli keluarga dalam penyediaan makanan yang bergizi bagi anak juga akan meningkat. Dengan demikiann status gizi anak akan menjadi baik.

Peran ayah tidak hanya berkaitan dengan upaya pemenuhan gizi. Harmaini, dkk (2014) mengatakan bahwa peran serta yang dilakukan ayah dalam merawat anak bisa dilihat dari upaya pemenuhan kebutuhan afeksi (misalnya memberikan perhatian memberikan rasa aman dan kebahagiaan dan sejenisnya), pengasuhan (misalnya memberikan nasehat, menjaga, meluangkan waktu dan sejenisnya) dan pemberian dukungan finansial (misalnya memenuhi kebutuhan).

Biblio-journaling adalah sebuah upaya yang dapat dilakukan untuk optimalisasi peran ayah pada 1000 HPK sehingga diharapkan dapat mewujudkan tumbuh kembang balita secara optimal, dan dampak jangka panjangnya dapat menurunkan kejadian stunting. Selain itu, diharapkan juga bisa menjadi salah satu wujud upaya untuk memberikan pengetahuan dan keterampilan kepada para ayah dan anggota keluarga lain tentang cara mengasuh serta memperhatikan asupan gizi serta kesehatan balita.

Penyelenggaraan biblio-journaling pada penelitian ini dilakukan melalui tahap sebagai berikut:

1. Bibliotherapy

Pada pelaksanaan teknik bibliotherapy peneliti menyiapkan bahan bacaan khusus yang harus dibaca oleh ayah. Adapun cakupan materi bahan bacaan yang disiapkan oleh peneliti berisi tentang:

a. Yang perlu diketahui ayah dan ibu. Apa sih itu stunting?

Pada bab ini disajikan bahan bacaan tentang pengertian stunting; faktor penyebab stunting; dan upaya pencegahan stunting.

b. Pra-kehamilan

Pada bab ini disajikan bahan bacaan tentang pengetahuan tentang gizi selama masa kehamilan beserta fungsinya; tips memenuhi nutrisi ibu hamil; dan bentuk peran ayah dalam keluarga.

c. Trimester 1 Kehamilan

Pada bab ini disajikan bahan bacaan tentang fase pertumbuhan dan perkembangan janin pada trimester ke-1 kehamilan, nutrisi yang diperlukan pada masa kehamilan beserta kegunaannya untuk menunjang nutrisi yang dibutuhkan oleh ibu hamil; dan peran ayah pada trimester ke-1 kehamilan ibu.

d. Trimester 2 Kehamilan

Pada bab ini disajikan bahan bacaan tentang fase pertumbuhan dan perkembangan janin pada trimester ke-2 kehamilan, nutrisi yang diperlukan pada masa kehamilan beserta kegunaannya untuk menunjang nutrisi yang dibutuhkan oleh ibu hamil; dan peran ayah pada trimester ke-2 kehamilan ibu.

e. Trimester 3 Kehamilan

Pada bab ini disajikan bahan bacaan tentang fase pertumbuhan dan perkembangan janin pada trimester ke-3 kehamilan, nutrisi yang diperlukan pada masa kehamilan beserta kegunaannya untuk menunjang nutrisi yang dibutuhkan oleh ibu hamil; dan peran ayah pada trimester ke-3 kehamilan ibu.

f. Periode Pasca Melahirkan (Bayi 0-2 tahun)

Pada bab ini disajikan bahan bacaan tentang fase pertumbuhan dan perkembangan anak pada usia 0-2 tahun; dan peran ayah dalam mendampingi fase pertumbuhan dan perkembangan anak usia 0-2 tahun. 


\section{Journaling therapy}

Pelaksanaan teknik journaling therapy dilakukan sejalan dengan pelaksanaan bibliotherapy. Journaling dilakukan setiap akhir sub tahap bibliotherapy. Tujuannya adalah untuk mengetahui wawasan yang berhasil dikuasai oleh ayah setelah membaca bahan bacaan yang telah disiapkan. Disamping itu, ayah diberikan ruang untuk menuliskan refleksi atas pengalaman yang dialaminya selama mendampingi ibu hamil dan perkembangan anak balita. Pada saat membuat refleksi, ayah diminta untuk menuliskan pengalaman pengasuhan kesehariannya kemudian dibandingkan dengan wawasan yang diperolehnya dari bahan bacaan. Ayah diminta untuk menganalisis ada atau tidaknya kesenjangan diantara keduanya. Jika ditemukan ada kesenjangan antara wawasan yang diperoleh dengan kenyataan yang dilakukan atau dialaminya, maka ayah diminta untuk menuliskannya secara jujur dan terbuka pada lembar journaling. Refleksi pengalaman yang disampaikan oleh ayah dituangkan dalam sebuah buku khusus yang disiapkan oleh peneliti. Tulisan hasil refleksi yang dilakukan oleh ayah, selanjutnya digunakan sebagai topik pembahasan pada pertemuan sesi konseling kelompok.

Penyelenggaraan teknik biblio-journaling ini dipadukan dengan konseling kelompok yang melibatkan ayah. Konseling kelompok diselenggarakan secara berkala untuk menindaklanjuti hasil bibliotherapy dan journaling therapy yang dilakukan oleh ayah di luar pertemuan konseling kelompok. Pada sesi konseling kelompok, secara bergantian setiap anggota kelompok diberikan kesempatan untuk menyampaikan hasil refleksi yang telah dituangkan dalam lembar journaling. Jika ditemukan permasalahan, maka dinamika kelompok yang terjadi pada sesi konseling dapat dimanfaatkan untuk menyelesaikannya.

Berdasarkan paparan tersebut maka dapat dikatakan bahwa dalam pengasuhan anak, terutama pada 1000 Hari Pertama Kehidupan, ayah memiliki peran yang khas pada setiap tahapan perkembangan anak, terlebih dalam fase kehidupan yang dimulai sejak terbentuknya janin pada saat kehamilan (270 hari) sampai dengan anak berusia 2 tahun (730 hari). Keterlibatan ayah dalam pengasuhan merupakan keikutsertaan positif ayah dalam kegiatan yang berupa interaksi langsung dengan anak-anaknya.

Pada dasarnya Biblio-Journaling merupakan salah satu layanan yang ada dalam Bimbingan dan Konseling yang dapat menangani beragam masalah, meskipun banyak studi hasil memfokuskan pada klien- klien yang mengalami depresi dan kecemasan dengan tujuan membantu memisahkan masalah dari diri menurunkan gejala-gejala dan perilaku bermasalah dan membantu perkembangan perasaan berdaya, namun teknik ini juga dapat digunakan untuk optimalisasi peran ayah pada 1000 hari pertama kehidupan (HPK) sebagai upaya menurunkan stunting.

\section{SIMPULAN}

Berdasarkan hasil penelitian dan pembahasan maka diambil kesimpulan bahwa biblio-journaling dapat meningkatkan pemahaman ayah tentang stunting sehingga peran ayah pada 1000 Hari Pertama Kehidupan (HPK) menjadi optimal sebagai upaya menurunkan kejadian stunting. Peran aktif ayah dalam pengasuhan dilakukan dengan meningkatkan pengetahuan tentang stunting, menjaga stabilitas gizi keluarga dan memenuhi kebutuhan fisiologis dan psikologis ibu dan anak. Peran ayah dimulai saat mendampingi masa kehamilan ibu hingga anak berusia lima tahun. Peran tersebut diperlukan untuk menjamin tumbuh kembang anak secara optimal dan terbebas dari masalah kesehatan, salah satunya adalah terbebas dari stunting. 


\section{UCAPAN TERIMAKASIH}

Penulis mengucapkan terima kasih kepada BKKBN Propinsi Jawa Timur yang telah mendukung pelaksanaan penelitian ini melalui bantuan pendanaan dari BKKBN Propinsi Jawa Timur Tahun 2019.

\section{DAFTAR PUSTAKA}

Arikunto, S. (2010). Manajemen Penelitian. Rineka Cipta.

Arikunto, S. (2013). Manajemen Penelitian. Rineka Cipta.

Atmarita. (2018). Asupan Gizi yang Optimal untuk Mencegah Stunting. Buletin Jendela Data Dan Informasi Kesehatan, 14-25.

Direktorat Pembinaan Pendidikan Keluarga. (2019). Modul Pendidikan Keluarga Pada 1000 Hari Pertama Kehidupan (HPK). Direktorat Jenderal Pendidikan Anak Usia Dini dan Pendidikan Masyarakat Kementerian Pendidikan dan Kebudayaan.

Eliasa, E. . (2011). Bibliotherapy as a Method of Meaningful Treatment.

Erford, B. . (2016). 40 Teknik yang Harus Diketahui Setiap Konselor. Pustaka Pelajar.

Folastri, S., \& Rangka, I. . (2016). Prosedur Layanan Bimbingan dan Konseling Kelompok (Panduan Praktis Menyeluruh). Mujahid Press.

Harmaini, Shofiah, V., \& Yulianti, A. (2014). Peran Ayah dalam Mendidik Anak. Jurnal Psikologi, 10(2), 80-85.

Herlina. (2013). Bibliotherapy: Mengatasi Masalah Anak dan Remaja Melalui Buku. Pustaka Cendekia Utama.

Herwanti, E. (2017). Hubungan Peran Ayah Dalam Upaya Perbaikan Gizi Dengan Status Gizi Balita Pada Masyarakat Budaya Patrilineal di Desa Toineke dan Taufanu Puskesmas Kualin Kabupaten Timor Tengah Selatan. Seminar Nasional "Kolaborasi Interprofessional Kesehatan Untuk Meningkatkan Kualitas Hidup Manusia Indonesia Dengan Pendekatan Keluarga Sehat." https://www.poltekkeskupang.ac.id/informasi/download/category/60-seminarnasional-agustus-2017.html\#

Hidayati, F., Kaloeti, D. V. ., \& Karyono. (2011). Peran Ayah dalam Pengasuhan Anak. Jurnal Psikologi Undip, 9(1), 1-10.

Ibrahim, I. ., \& Faramita, R. (2015). Hubungan Faktor Sosial Ekonomi Keluarga dengan Kejadian Stunting Anak Usia 24-59 Bulan di Wilayah Kerja Puskesmas Barombong Kota Makassar Tahun 2014. Al-Sihah: Public Health Science Journal, 7(1), 63-75.

Izwardy, D. (2020). Studi Status Gizi Balita Terintegrasi Susenas 2019. Rakerkesnas. https://www.kemkes.go.id/resources/download/info-terkini/Rakerkesnas-

2020/02-Side-event/SE_08/Studi Status Gizi Balita Terintegrasi SUSENAS 2019 (Kapus Litbang UKM).pdf

Johnson, M. (2012). Bibliotherapy and Journaling as a Recovery Tool with African Americans with Substance Use Disorders. Alcoholism Treatment Quarterly, 30(3), 367-370. https://doi.org/10.1080/07347324.2012.691042

Kementerian Desa, P. D. T. dan T. (2017). Buku Saku Desa dalam Penanganan Stunting. Kementerian Desa, Pembangunan Daerah Tertinggal dan Transmigrasi.

Kementerian PPN/Bappenas. (2019). Musrenbangnas RPJMN 2020-2024: Indonesia Lanjutkan Pembangunan Infrastruktur untuk Modal Persaingan Global. Berita Utama. https://www.bappenas.go.id/id/berita-dan-siaran-pers/musrenbangnasrpjmn-2020-2024-indonesia-lanjutkan-pembangunan-infrastruktur-untuk-modalpersaingan-global/

Masrul. (2019). Gambaran Pola Asuh Psikososial Anak Stunting dan Anak Normal di Wilayah Lokus Stunting Kabupaten Pasaman dan Pasaman Barat Sumatera Barat. 
Jurnal Kesehatan Andalas, 8(1), 112-116.

Ni'mah, C., \& Muniroh, L. (2015). Hubungan Tingkat Pendidikan, Tingkat Pengetahuan dan Pola Asuh Ibu dengan Wasting dan Stunting pada Balita Keluarga Miskin. Media Gizi Indonesia, 10(1), 84-90.

Oluwaseye, A. J. (2017). Bibliotherapy.

Pritasari, K. (2020). Arah Kebijakan dan Rencana Aksi Program Kesehatan Masyarakat Tahun 2020-2024. Rakerkesnas. https://www.kemkes.go.id/resources/download/info-terkini/Rakerkesnas2020/Pleno 2/Arah dan kebijakan Program Kesehatan Masyarakat tahun 2020 2024 (Ditjen Kesmas).pdf

Rahayu, A., \& Khairiyati, L. (2014). Risiko Pendidikan Ibu Terhadap Kejadian Stunting Pada Anak 6-23 Bulan. Penel Gizi Makan, 37(2), 129-136.

Rakhmawati, I. (2015). Peran Keluarga dalam Pengasuhan Anak. KONSELING RELIGI: Jurnal Bimbingan Konseling Islam, 6(1), 1-18.

Redaksi Sahabat Keluarga. (2018). Ayah, Anda Berperan Sentral dalam Menanggulangi Stunting! Sahabat Keluarga. Kementerian Pendidikan Dan Kebudayaan. https://sahabatkeluarga.kemdikbud.go.id/laman/index.php?r=tpost/xview\&id=249 900174

Sanyata, S. (2010). Teknik dan Strategi Konseling Kelompok. Paradigma, 5(9), 105-120.

Setiawan, B. (2018). Faktor-faktor Penyebab Stunting Pada Anak Usia Dini (E. Yulaelawati (ed.)). Yayasan Rumah Komunitas Kreatif.

Shechtman, Z. (2009). Bibliotherapy as a Method of Treatment. In Treating Child and Adolescent Aggression Through Bibliotherapy (p. 239). Springer. http://www.springer.com/978-0-387-09743-5

Siregar, S. (2011). Statistika Deskriptif untuk Penelitian Dilengkapi Perhitungan Manual dan Aplikasi SPSS Versi 17. RajaGrafindo.

Suca, U. ., Fajar, N. ., \& Idris, H. (2019). Analisis Aspek Biologis dan Psikologis Ibu Terhadap Stunting Balita Keluarga Miskin di Kota Palembang. Jurnal Kesehatan Vokasional, 4(2), 65-69.

Sugiyono. (2008). Statistika Untuk Penelitian. Alfabeta.

Undang-undang Nomor 36 tahun 2009 tentang Kesehatan, 111 (2009).

WHO. (2010). Nutrition Landscape Information System (NLIS) country profile indicators: interpretation guide. WHO Press.

WHO. (2014). Global nutrition targets 2025: stunting policy brief (WHO/NMH/NHD/14.3). World Health Organization. 